\title{
55 キャビティ付多孔壁による凝縮衝撃波の制御
}

佐賀大瀨戸口俊明 ${ }^{\circ}$, 富永隆, 中野智弘, 金子賢二

Control of Condensation Shock Wave Using Porous Wall with Cavity

Toshiaki SETOGUCHI*, Takashi TOMINAGA*, Toshihiro NAKANO* and Kenji KANEKO*

Since the concept of passive control of shock-boundary layer interaction was published in 1983, many papers have been reported on the application of this technique to transonic airfoil flows. In the present paper, this technique is applied to condensation shock wave which is caused by rapid expansion of moist air in a supersonic nozzle. The effects of passive control on condensation shock wave have been experimentally investigated by a schlieren optical method and by pressure measurements. As a result, it is found that passive control is the useful technique to suppress the periodic oscillation of condensation shock wave.

\section{1・まえがき}

比較的潜熱量の大きい凝縮性気体、特に、水蒸気や湿り空気などが、ラバルノズルで急 激に加速膨張する場合、飽和状態に達しても凝縮せず過飽和状態となりノズル内で非平衡 凝縮が起こるい”。の凝縮により流れは気液二相の噴蓩流となり、潜熱放出の影響で流れ の状態が変化し、ノズル内に凝縮衝撃波が形成されるい。更に、ノズル口における流れ の飽和度が比較的高い場合には、凝縮衝揧波は上流に伝ぱし、ノズル内の流れが周期的に振 動する(2)。このような現象は蒸気タービン内の膨張流れなどに関連して従来多くの研究が 報告されている。しかし、凝縮衝撃波による流れ場への影響を少なくするための制御法に 関する研筧はほとんど行われておらず、特に自励振動する凝縮衝撃波に対する対策は重要 な課題となっている。

ところで、最近、衝撃波と境界層の干涉を受動的に制御する方法(パッシフコントロール) が注目されている。これは、衝撃波が発生する位置の壁面をキャビティ付多孔壁として、衝 揧波自体の特性により境界層制御を行うことで、衝揧波による流れ場への影響を小さくし ようとするものである(3)(4)。

本研窥は、キャビティ付多孔壁用いるパッシブコントロールをラバルノズル内で発生す る凝維衝撃波に適用し、をの有用性を実験的に調べたものである。

2 . 実験装置と方法

本研究で使用した超音速風洞の概要を図1に示す。風洞は、大気圧状態の湿り空気を真空 タンクに吸い込む形式で、貯気槽 $\left(15 \mathrm{~m}^{3}\right) 、$ 測定部おょび真空タンク $\left(1.8 \mathrm{~m}^{3}\right)$ から構成されて いる。测定部は高さが $60 \mathrm{~mm}$ 幅が $38 \mathrm{~mm}$ 柇断面で、上壁に先絴末広円弧ノズル(ハーフノズ

* Faculty of Science and Engineering, Saga University, 1, Honjo, Saga-shi, Saga, 840, Japan. 
ル曲率半径 $R^{*}$ が $155 \mathrm{~mm}$ と $400 \mathrm{~mm} 、$ スート高 さ $h^{*} / 2=24 \mathrm{~mm}$ )が装着されている。またハー フノズルには、図2に示すようにノズルス ロートよりキャビティ付多孔壁が設けられ ている。キャビティ長さは $20 \mathrm{~mm}$ 、樑さ $D$ は 3 $\mathrm{mm}\left(R^{*}=400 \mathrm{~mm}\right)$ と $5 \mathrm{~mm}\left(R^{*}=155 \mathrm{~mm}\right)$ で、多孔壁 は図2(b)に示すようにめ2mmの孔がピッ $5 \mathrm{~mm}$ の間隔で4列に配され、孔数を変化させ ることで空腺率 $P$ (孔の総面積と多孔壁領域面積 の比)を0.05、0.10、0.13、0.18の4種類とした。

実駼に際し、眝気槽の压力 $D$ 。 温度 $T$ 。と相対湿度 $\phi_{0}$ を熱電対と相対湿度計で測 定し、それぞれ電熱器と超音波加湿器を用いて所 定の值に設定する。本装置では、測定部下流のバ ルブを開放すると貯気槽内の湿り空気が真空タン クに流れ込み、测定部において持続時間が約 3 秒 の定常な超音速流れが得られ、その問に下壁に接 して配されたスルーチューブ(のにより流れ方向 の圧力計測（KULITE社製、タイプCQ-62）、シュリ ーレン法により流れ場の可視化を行った。

3 . 実験結果と考察

3. 1 凝縮衝撃波の可視化凝縮衝揧波形

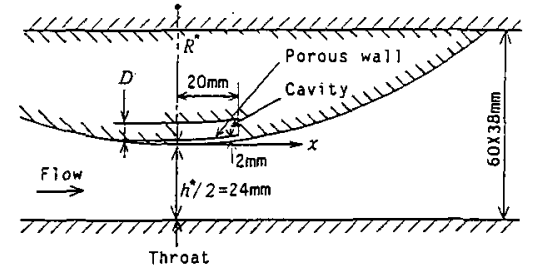

(a) Test section

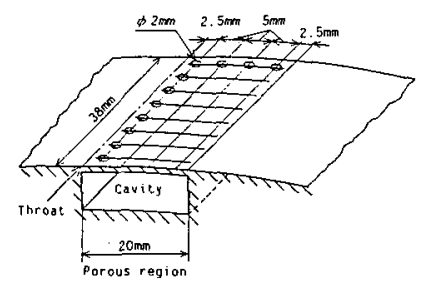

(b) Porous wal1

Fig.2 Test section and porous wall 状に及ぼすパッシブコントロールの影響を图 3 に 示す。眓 $3(\mathrm{a})$ は固体壁の場合で、相対湿度 $\phi$ 。の增加とともに㠜縮衝繋波は明確になり、 その発生位置がスロートに近つく。一方、図3(b)は、P=0.18の多孔壁を有する場合であ

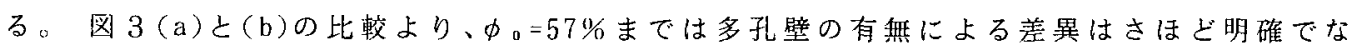
い。これは、多孔壁と㠜縮衝撃波の相対位㯰が適切でないためである。しかし 上では、凝縮衝撃波の分枝が観察され、㠜縮衝撃波の強さが弱くなっている。これは多孔壁 面上に凝縮衝撃波が位置するため、凝縮衙慗波自体の特性により流れ場の調整が行われる ためである(る)。

以上の結果は、ラバルノズル内に凝縮衝揧波が定在する場合であるが、め。がさらに增加 すると凝縮衝撃波は流れ場に定在できず、自励振動(2)を起こす。図 4 はその代表写真 $\left(R^{*}\right.$ $=155 \mathrm{~mm}$ )で、(a) $\rightarrow(\mathrm{d})$ は時間の経過を示す。図より明らかなように、(a)で発生した㠜縮衝慗 波は、(b)、(c)と時間が経過する上明確になるとともにノズルスロートに近づき、やがてス ロートを通過(d)して上流に伝ばする。その後、再び(a)の状熊に至る。また、R* $=400 \mathrm{~mm}$ の場 合も図4と同様な現象が観察された(図略)。凝縮衝撃波の自励振動に及ぼすパッシブコン トロールの効果であるが、 $P=0.05$ の場合は図 4 とほほ同じパターンの写真が得られたが 

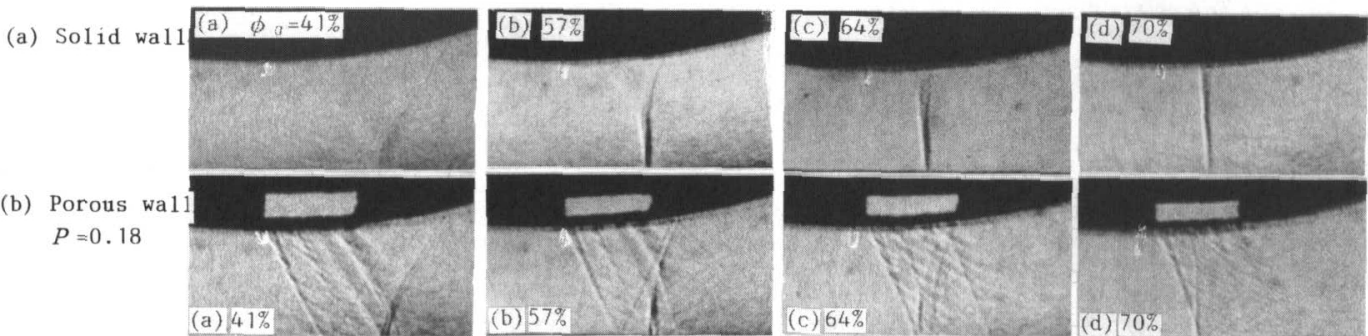

(b) Porous wa1
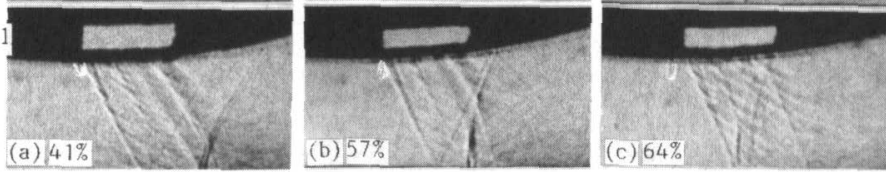

d) $70 \%$

Fig. 3 Sch1ieren photographs showing condensation shock wave $\left(p_{0}=101.3 \mathrm{kPa}, T_{0}=303 \mathrm{~K}, R^{*}=155\right)$
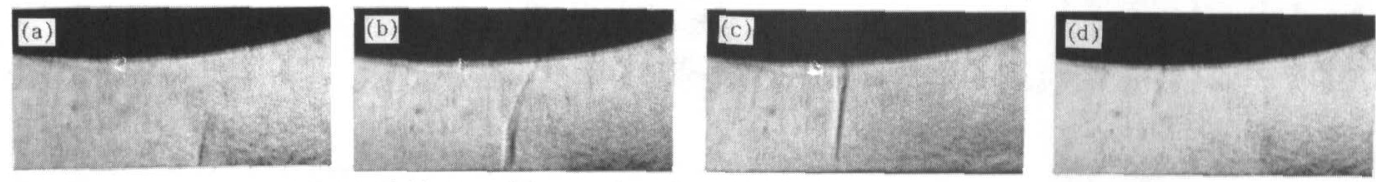

Fig.4 Sh1ieren photographs of periodic flow caused by condensation $\left(p_{0}=101.3 \mathrm{kPa}, T_{0}=303 \mathrm{~K}, \phi_{n}=79 \%, R^{*}=155\right)$

$P \geqq 0.10$ では図 5 に示すように凝縮衝撃波は観察 されなかった。これは、伝ばする凝縮衝撃波の強 さが、その伝ぱ過程において多孔壁からの吸込み により弱められるためと思われ、同様な現象は、多 孔壁面内を伝ぱする衝撃波の研究においても観察 されている(日)。

3. 2 定在する凝縮衝撃波に及ぼす影響 図 6 は、静圧分布に及ばすパッシブコントロール の影響を $\phi_{0}=64$ と $70 \%$ に対して示す。図の横軸はノ ズルスロートからの距離 $x$ を $h^{*}$ で無次元化した $x / h^{*}$ 、縌軸は局所静压 $p$ とよどみ圧力 $p_{0}$ の比 $p$ 力。である。図より凝縮領域における圧力上昇は、 パッシブコントロールにより低くなることがわか る。また等エンロピ線から圧力分布がずれ始める 位置が、パッシブコントロールにより上流側に移 動することもわかる。これは、凝縮衝撃波が分枝 するためである。

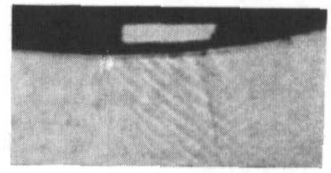

Fig. 5 Sch1ieren photographs showing effect of passive control on periodic flow caused by condensation $\left(p_{0}=101.3 \mathrm{kPa}\right.$, $T_{0}=303 \mathrm{~K}, \phi_{0}=79 \%, P=0.13, R^{*}=155$ )

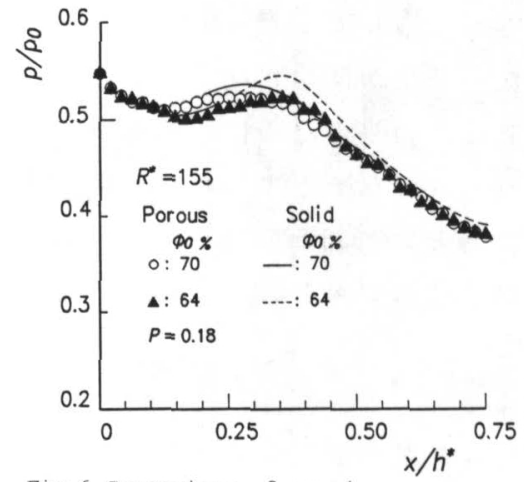

Fig. 6 Comparison of static pressure distributions between solid wall and porous wa11 $\left(p_{0}=101.3 \mathrm{kPa}\right.$, $T_{0}=303 \mathrm{~K}$ )

図 7 は、凝縮領域の最大圧力值 $p_{2}$ と等エンロピ線から圧力がずれ始める位置の圧力値 $p_{1}$ の比 $p_{2} / p_{1}$ を $\phi_{0}$ に対して示す。図の $\phi_{0}$ の範囲では、 $p_{2} / p_{1}$ は $\phi_{0}$ 茂増加すると小さ くなる。これは、凝縮の開始点が $\phi$ 。とともにノズルスロートに近つくためである。また $P$ が大きいほど $p_{2} / p_{1}$ は小さくなるが、その効果は $\phi$ 。が小さいほど大きい。これは、 $P$ が大 きいほど凝縮衝撃波下流における吸込み作用が大きくなるためである。

3. 3 自励振動する凝縮衝撃波に及ぼす影響—凝縮衝撃波の自励振動に及ほすパッ シブコントロールの影響を図 8 に示す。図は、固体壁と多孔壁の場合 $\left(R^{*}=155 \mathrm{~mm}\right)$ の $x / h^{*}$ 
$=0 、 0.25 、 0.50$ におる圧力の時間的変化を示す。 図（a）の固体壁の場合には、図4で示したようにス ロ一トを通過して上流に伝ぱする凝縮衝慗波のた めに周期的な振動現象がみられる。振動の周波数 は、 $x / h^{*}$ に関係なく同じであるが、振幅は $x / h^{*}$ $\doteqdot 0.25$ で最大となる。一方、多孔壁の場合には、 $P=$ 0.05 では振動現象は存在するものの振幅はかなり 弱くなっており、P=0.10では振動現象は生じてい ない。これらは前述のように、多孔壁による吸远 み作用のため㠜縮衝撃波が弱くなるため上思われ 万。

図9は、ノズルスロートにおける凝縮衝揧波の 自励振動の無次元周波数 $\vec{f}\left(=f h * 0.795 R^{* 0.205}\right.$ : $u^{*} 、 u^{*}:$ イスルスロートに求ける流速)(2)上相 刘湿度 $\phi 。 の$ 関係を示す。図より、R* $=155 \mathrm{~mm}$ 場合、 本奏験範国では $P \geqq 0.10$ で㠜縮衝撃波の自励振動 が起こらず、 $P=0.05$ では固体壁の場合より高い $\bar{f}$ 值となることがわかる。 $P=0.05$ の場合に振動の周 波数が高くなるのは、固体壁では凝縮衝撃波がス ロートを通過して上流に伝ぱした捘に新たな凝縮 衝撃波の発生が開始されるのに対し、多孔壁では その吸込み効果のために㠜縮衝撃波の生滅が短時 間に行われるためと思われる。なお $R^{*}=400 \mathrm{~mm}$ 場合にも $R^{*}=155 \mathrm{~mm}$ 場合と同じ結論が得ら扎た が、図中には $P=0.13$ の多孔壁の效果のみを示し ている。

\section{4.まとめ}

凝縮衝撃波の制御にキャビティ付多孔壁による パッシブコントロールを適用し、本コントロール が特に凝縮衝撃波の自励振動の抑制に有効である ことを示した。

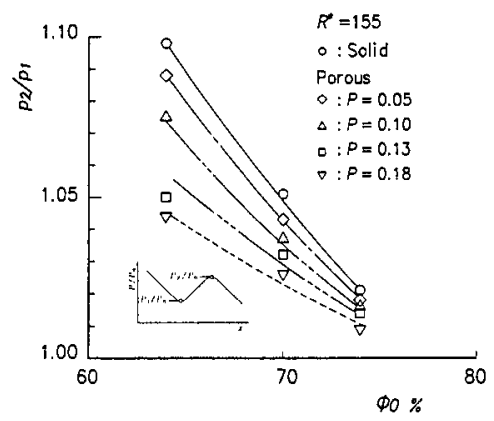

Fig.7 Relation between pressure ratio $D_{2} / D_{1}$ and relative humidity $\phi_{0}$ $\left(p_{0}=101.3 \mathrm{kPa}, T_{0}=303 \mathrm{~K}\right)$

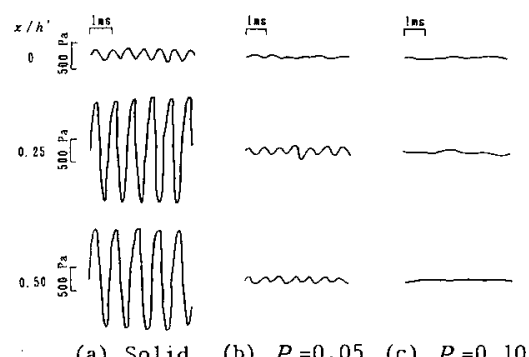
(a) Solid
(b) $P=0.05$
(c) $P=0.10$

Fig.8 Typical examples of pressure change with time $\left(p_{0}=101.4 \mathrm{kPa}\right.$, $T_{0}=300 \mathrm{~K}, \phi_{0}=83 \%, R^{*}=155$ )

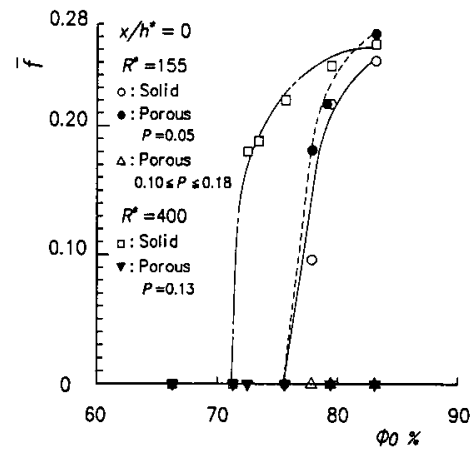

Fig.9 Relation between non-dimensiona 1 frequency and relative humidity $\left(p_{0}=101.4 \mathrm{kPa}, T_{0}=300 \mathrm{~K}\right)$

文献（1）松尼・はか3名, 機械の研范, 36-1(1984),73.（2)松尾・ほか3名, 機械の研究, 365(1984)，642．（3)瀬戸口，S.Raghunathan, 機珹の研究，43-4(1991)，463.（4)瀬戸口, S.Raghunathan, 機械の研究, 43-5(1991),566. (5)Matsuo,K., et al, Proc. 2nd KSME-JSME Fluids Eng. Conf., (1990), 64. (6)Deckker, B. E. L., et al., Proc. 14 th Int. Symp. on Shock Tubes \& Taves, $(1983), 239$. 